\title{
A New Strategy for Pre-Selecting Gas Wells for the Water Shut-Off Treatment Based on Geological Integrated Data
}

\author{
Sławomir Falkowicz, Andrzej Urbaniec (D), Marek Stadtmúller*D and Marcin Majkrzak \\ Oil and Gas Institute-National Research Institute, 25A Lubicz Str., 31-503 Krakow, Poland; \\ falkowicz@inig.pl (S.F.); urbaniec@inig.pl (A.U.); majkrzak@inig.pl (M.M.) \\ * Correspondence: stadtmuller@inig.pl
}

Citation: Falkowicz, S.; Urbaniec, A.; Stadtmúller, M.; Majkrzak, M. A New Strategy for Pre-Selecting Gas Wells for the Water Shut-Off Treatment Based on Geological Integrated Data. Energies 2021, 14, 7316. https:// doi.org/10.3390/en14217316

Academic Editor:

Marcin Kremieniewski

Received: 21 September 2021

Accepted: 29 October 2021

Published: 4 November 2021

Publisher's Note: MDPI stays neutral with regard to jurisdictional claims in published maps and institutional affiliations.

Copyright: (c) 2021 by the authors. Licensee MDPI, Basel, Switzerland. This article is an open access article distributed under the terms and conditions of the Creative Commons Attribution (CC BY) license (https:// creativecommons.org/licenses/by/ $4.0 /)$.

\begin{abstract}
This article presents a new analytical procedure for pre-selecting gas wells for water shutoff treatments based on available at hand results of an analysis of integrated geological, reservoir and exploitation data. Attention was paid to assess the possibility of the appearance of cross flows between layers in the near wellbore zone. Their appearance always eliminated the well as a candidate for the treatment. The basis for assessing the possibility of the emergence of cross flows was based on the assessment of the presence or absence of impermeable barriers (e.g., shales or anhydrite) in intervals, completed by perforation. For this assessment, well logging data were used, which were carried out in different years with the use of various types of probes. Based on modified quantitative and qualitative interpretation techniques, permeable and impermeable layers were separated in the analysed borehole sections. In some cases, in the absence of other data, well logs are the only source of information from which a vertical profile of horizontal permeability can be made. The article describes the verification process carried out for the eight wells situated in the area of the Carpathian Foredeep, which have been preselected by the operator. As part of this procedure, the available geological, reservoir and exploitation data were used, and a preliminary assessment of the possibility of implementing the obtained results into other wells and gas fields in the area of the Carpathian Foredeep was carried out. On the basis of the well ranking, two out of the eight analysed wells were recommended as candidates for water shut-off treatment.
\end{abstract}

Keywords: water shut-off treatment; gas production; water-gas ratio (WGR); formation permeability; well logging data quality and quantity interpretation; gas well ranking

\section{Introduction}

One of the most serious problems arising during the exploitation of hydrocarbons is the high production of water in oil and gas wells. This has a negative impact on the economics of the exploitation of hydrocarbon formations. It is estimated that the world production of water in oil wells reaches a level of 75 billion barrels, and its disposal costs exceed 40 billion dollars [1]. In the United States alone, oil wells produced 21 billion barrels of reservoir water in 2007 [2], and in 2017 over 24.4 billion barrels [3].

Approximately 4.5 billion $\mathrm{m}^{3}$ of natural gas is produced in Poland annually. Assuming a water-gas ratio (WGR) at a level of $0.1 \mathrm{~kg} / \mathrm{m}^{3}$, it can be assumed that gas production is accompanied by annual production of water in the amount of 450 thousand tonnes. Assuming the cost of managing/disposing of water at USD 40/tonne, this gives an amount equal to USD 18 million. In addition, especially in the late period of exploitation of the formation, the produced water significantly reduces gas production, often to an economically unacceptable level, which leads to the well being shut off [4]. While there may be many reasons for the high water production, for effective treatment, the source of the problem must first be correctly identified.

The next step involves selecting the most suitable technology for this and adapting it to local conditions. It should be remembered that no two cases are the same, not only 
for the same formation, but even for adjacent wells. Therefore, the selection of the target production/injection well is of key importance and should be based on the available formation and exploitation data [4].

Again, correctly determining the cause of a high WGR is the basis of success in water shut-off treatments. Unfortunately, operators often underestimate this important initial step. There are many reasons for this. For example, correct assessment requires time and effort, and it is not always known which of the solutions will turn out to be profitable. In addition, many service companies wrongly believe that there is only one way to fix a problem, or that all problems come from the same source. Some service companies argue that they have one universal solution that works for all cases. As previously emphasised, in water production limitation there is no one universal solution of the problem, and due to the complexity of the problem, no more than $80 \%$ of field operations can be classified as technically successful and no more than $60 \%$ as profitable [5].

In many cases of an excessive, uncontrolled inflow of water to a production well, the reason of the problem is incorrectly assumed. Often, specialists incorrectly believe that only one type of water production problem (e.g., three-dimensional coning) exists, while an appropriate analysis of the available data and a correct diagnosis may indicate the true cause, e.g., flow behind pipe or a two-dimensional coning. This knowledge enables the implementation of an appropriate "repair" program, ensuring a greater probability of success of the performed procedure.

After identifying the causes of water breakthrough to the production well, countermeasures should be introduced that will use the simplest possible solutions to resolve this problem. Based on an extensive analysis of formation and engineering data, 13 causes and water breakthrough mechanisms were identified. They were collected in four categories, from $\mathrm{A}$ to $\mathrm{D}$, depending on the countermeasures to be taken to address the problem of excessive water production by the well, precisely described in literature $[4,6]$. There are two methods of reducing excess water production in hydrocarbon producing wells: mechanical and chemical. In chemical methods, special treatment fluids are injected into the formation in order to limit the permeability of rocks near the well in the water-producing layers. The most accepted by operators are the treatments defined as selective. In this case, without the mechanical isolation of the separated layers in the perforation interval, the treatment fluid is injected into the formation. As a result of contact with the formation water in the water bearing zone, it takes the form of a gel, completely or at least partially blocking the flow of water to the well.

Since the beginning of the 1980s, a popular method of reducing water production is the use of RPM (relative permeability modification) techniques. In these techniques, treatment fluids, most often based on polymers, are injected to a depth of 1 to $2 \mathrm{~m}$ into the formation, and adsorb on the formation rocks to reduce water production without reducing oil or gas production. [7]. Apart from the others, the effectiveness of RPM technique is related to the physical properties of pore walls of the formation rocks, which sometimes can be difficult to assess. In the case of fractured and pore-fractured formations, the injection of gels or gelants is applied, which results in the appearance of insulating barriers in specific parts of the formation. The factor initiating in-situ reactions in this type of treatment is the mixing of solutions, change of $\mathrm{pH}$, precipitation of insoluble particles and others.

It is difficult to accept that the same technology is often used for the exploitation of both oil and gas. The justification for this assessment is that:

- In oil/water systems, the movement of a fluid with higher mobility (water or gas) should be controlled by restricting or blocking the flow;

- In gas/water systems, the flow of a fluid with lower mobility (water) should be controlled by restricting or blocking the flow.

Consequently, selective control of water production in oil/water and gas/water systems requires a different theoretical approach and the use of other technologies and surface facilities [8]. 
In recent years, interesting concepts of using working fluids based on microemulsions in WSO treatments have appeared [9]. Hungarian specialists developed an innovative method, classified as reservoir conformance control (RCC) technology, which was successfully implemented in 16 gas wells [8,10]. RCC technology differs significantly from RPM methods developed so far. The RCC method provides a more radical intervention in the formation, consisting of the creation of insulating gel barriers deeper in the formation. Barriers of this type are assumed to:

- Effectively limit the flow of water to the well;

- Be more durable due to how they emerge;

- $\quad$ Not cause losses in the production of hydrocarbons.

Regardless of what liquid is used in WSO treatments, the condition for success is always the correct selection of the well where the treatment will be performed. The basis for the assessment is the correct determination of the water breakthrough mechanism to the well, which is presented in detail in some publications e.g., [6,11]. In the case of finding water breakthrough, which was described by Chan [12] as a channel, it should be absolutely specified whether after the treatment there will be flows of reservoir fluids between the layers, so-called "cross flows". The occurrence of cross flows or lack thereof depends mainly on the geological structure of the formation. Cross flows will occur when the water bearing zone and the pay zone are not isolated with impermeable barriers, or the ratio of the horizontal to vertical permeability $k_{h} / k_{v}$ of the perforated zone rocks is less than 10. This can be determined by several methods, but the results of pressure testing between zones are the most reliable. If it is not possible to perform such tests, flow profiles and well logs can also be helpful. In cases where it is not possible to determine whether there are impermeable barriers, it should be assumed that they do not exist. According to the authors of the article, the above assessment should be the first step in selecting a well as a candidate for WSO treatments. The further part of the article presents the procedure for confirming or excluding the presence of insulating impermeable barriers between the water and gas layers.

\section{Geological Background and Specification of the Selected Wells}

For the purpose of assessing the possibility of carrying out the procedure, the reduction of water production was initially designated by the operator of eight wells located in southeastern Poland (Figure 1a). In these wells, various gas-bearing horizons (in some cases more than one horizon) were located at different depths and were associated with both clastic and carbonate collectors. Taking into account the geological units, seven of the selected wells (C-2, J-5K, J-8K, P-6, T-3, Z-1K, Z-74) were located in the Carpathian Foredeep, and one (J-7) in the marginal part of the Outer Carpathians (Figure 1b).

Intervals saturated with natural gas selected for the analysis in six of the abovementioned wells (C-2, J-5K, J-8K, J-7, P-6, Z-74) were associated with multi-horizon gas fields, located within the profile of clastic formations of the autochthonous Miocene of the Carpathian Foredeep [16-23]. The gas-bearing horizons in the two remaining wells (T-3, Z-1K) represent massive gas formations, associated with a complex of Devonian carbonate rocks sealed with clay formations of the autochthonous Miocene or (locally) Carboniferous [24-26].

Generally, in the area of research, five main structural levels can be distinguished: (1) the series of Neoproterozoic anchimetamorphic rocks of the Ediacaran age, (2) the MesoPaleozoic rock complex, characterised by strongly diversified thicknesses and lithology, (3) the autochthonous Miocene formations which were initially deposited in the Carpathian Foredeep Basin, (4) the Miocene-age deformed sediments located in front of the Carpathian orogen, (5) the allochthonous formations traditionally included within several tectonic units of the Outer Carpathians. 


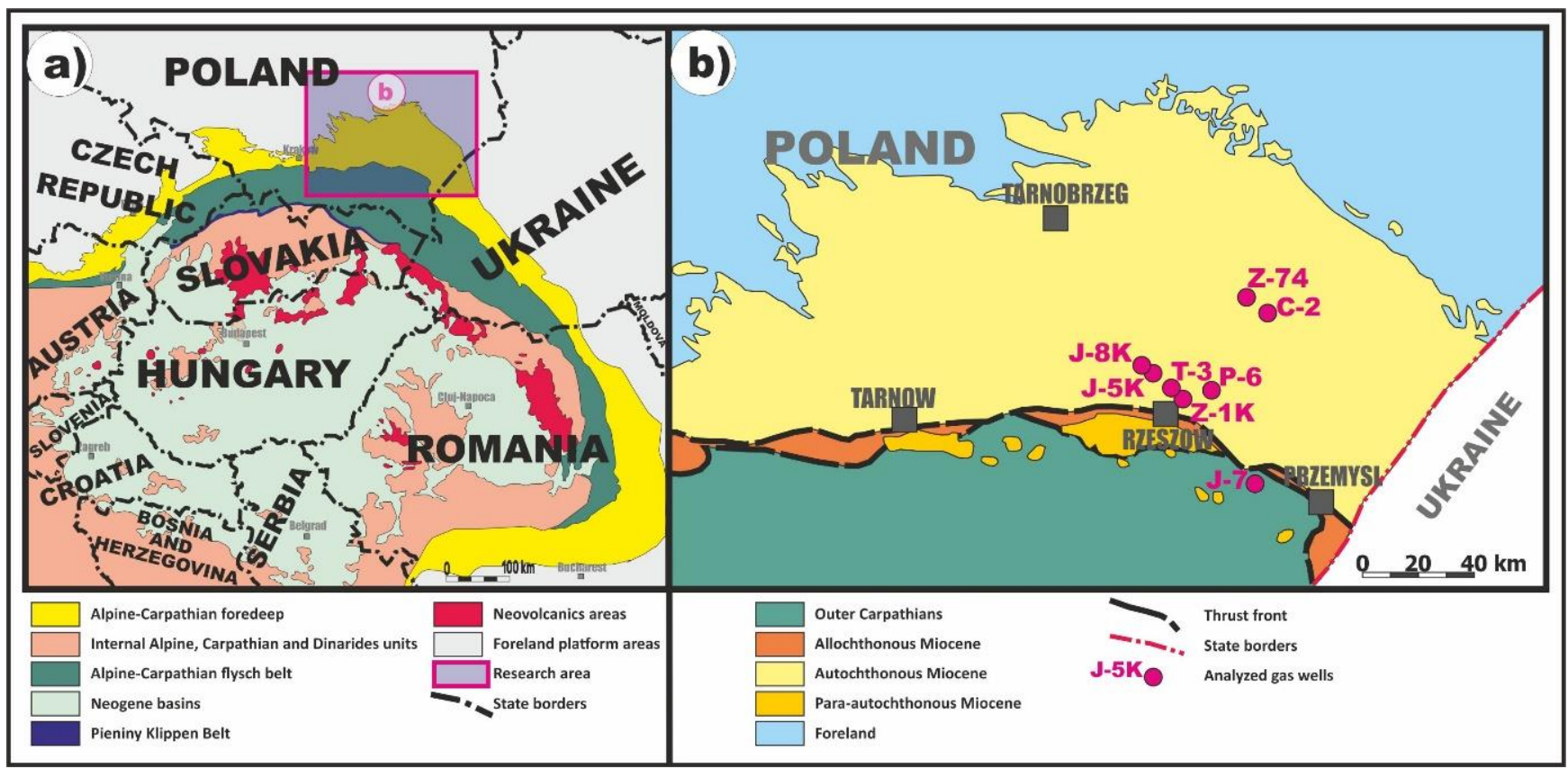

Figure 1. (a) Location of the study area in relation to the Carpathians and the Pannonian Basin System (PBS) (after Kováč et al. [13]; Golonka et al. [14]); (b) location of the analysed gas wells against the range of the eastern part of the Carpathian Foredeep in Poland; ranges of geological units according to Porębski and Warchoł [15].

\section{Characteristics of the Selected Wells}

All data used in the project were provided by the owner, Polish Oil and Gas Company (PGNiG SA), the operator of the studied wells. The collected data set included: exploitation data, parameters calculated for reservoir horizons, standard well logging data, geological documentation of fields. The quantity and quality of the data were sufficient to complete the study.

\section{The C-2 well}

The C-2 well is located in the NE part of the Carpathian Foredeep (Figure 1b). A total of three gas horizons were made available for exploitation in the upper part of the Miocene profile at a depth of about $250-300 \mathrm{~m}$. Based on the interpretation of the well logs, it can be stated that the horizons provided by the perforations are quite homogeneous in terms of lithology and reservoir properties. Short sections of perforation (up to $4 \mathrm{~m}$ ) provide only fragments of profiles of the identified gas-bearing horizons, characterised by better reservoir parameters.

The J-5K well

In the J-5K well, located in the central part of the research area (Figure $1 \mathrm{~b}$ ), one gas horizon, located in the middle part of the autochthonous Miocene profile, was included through a $17 \mathrm{~m}$ long perforation. Perforation provides the full profile of the gas horizon. The reservoir rock consists of sandy or mudstone rocks, genetically related to the delta environment [21]. Based on the interpretation of the well logs, it can be concluded that the profile of the analysed formation horizon is characterised by large lithological diversity and is composed of alternating layers of sandstone, mudstones and probably thin layers of claystone.

\section{J-8K well}

The J-8K well is located within the same gas field as the J-5K well. In this well, two perforation intervals ( $12 \mathrm{~m}$ and $6 \mathrm{~m}$ long) were selected for detailed analysis, which together complete the production of two gas horizons from the middle part of the autochthonous Miocene profile (including the same horizon as the J-5K, as well described above). The gas 
horizons clearly differ in terms of lithology, as the higher horizon is characterised by much greater lithological diversity and the associated differentiation of reservoir properties.

The J-7 well

The J-7 well is located in the SE part of the study area and as mentioned above, it is the only well located in the marginal part of the Outer Carpathians (Figure 1b). In this well, a wide $(50 \mathrm{~m})$ perforation interval covered two gas horizons identified in the autochthonous Miocene formations at a depth of less than $3000 \mathrm{~m}$. Miocene clastic formations occur in this zone in the substrate of allochthonous Carpathian formations. The trap is interpreted as a compact anticline, developed above the elevation of the Neoproterozoic basement [17]. The reservoir rock consists of layers of sandstone, silt and heteroliths, and the profile of the interval completed for production is characterised by large lithological diversity.

The P-6 well

The P-6 well is located in the central part of the research area. The selected interval includes two perforations (18 $\mathrm{m}$ long and $5 \mathrm{~m}$ long) providing one gas-bearing horizon located in the middle part of the Miocene profile at a depth of approx. 1450-1500 m. Generally, the lithological profile of the interval is similar to the above-mentioned profiles of the J-5K and J-8K wells, and is characterised by significant lithological diversity. The dominant lithotypes are heteroliths dominated by mudstone and heteroliths with equal proportions of sandstone and mudstone. The reservoir rock consists of sandstone layers with good reservoir parameters and sequences of heteroliths.

The T-3 well

The T-3 well is located within a massive gas deposit, developed in the upper part of the Late and Middle Devonian carbonate rock complex, lying at a depth of slightly less than $2000 \mathrm{~m}$. The reservoir rock consists of strongly fractured and sometimes also brecciated carbonate rocks (dolomites and limestones). The genesis of this reservoir formation is related to the intensive development of paleokarst processes, therefore, the gas-bearing horizon is very nonhomogeneous and is characterised by significant diversification of reservoir properties. The formation is sealed with Miocene claystone and mudstone formations. A $20 \mathrm{~m}$ long top part of the horizon has been completed for production.

The Z-1K well

The Z-1K well is located in close proximity to the T-3 well, on an adjacent gas field, which is very similar to the one described above. The reservoir rock consists of strongly brecciated and fractured dolomites and limestones, and the top seal is a series of impermeable fine-grained clastic sediments of the Lower Carboniferous. The reservoir properties are very diverse. An $18 \mathrm{~m}$ interval, located in the upper part of the horizon, at a depth below $2100 \mathrm{~m}$, was completed for the production in this well.

The Z-74 well

The Z-74 well is located in the NE part of the Carpathian Foredeep, not far from the C-2 well described above (Figure 1b). This well produced gas from a deeper part of the Miocene profile, which, according to the literature data, is generally associated with the complex of submarine fans $[19,27,28]$. The perforation is $8 \mathrm{~m}$ long and the gas-bearing horizon is composed of thin-layer rocks (most likely the dominant lithotype is heterolith dominated by mudstone).

\section{Initial Assessment of the Suitability of Wells for WSO Treatments Based on the Analysis of Diagnostic Plots}

One of the commonly used methods for identifying the water breakthrough mechanism to the well is the analysis of the history of changes in the WGR and its derivative as a function of time. The correct diagnosis of the "water problem" is a key element in indicating an effective method (mechanical or using treatment fluids) for limiting the production of formation water $[6,8,29]$. The method proposed by Chan [12] consists of comparing the changes in the WOR/WGR and its derivative obtained as a result of computer simulations 
in idealised operating conditions, with the history of changes in the indicated parameters in the analysed well. According to the cited methodology, there are three basic mechanisms of water inflow to the well, which have a significant negative impact on the production of hydrocarbons $[1,12,30]$ :

- Flow behind pipe or by fracture/fault, characterised by a sharp increase in the water ratio curve and its rapid stabilisation at a high level;

- Channel flow, also distinguished by a rapid increase in the water ratio (as a result of the flow of the formation water through the full cross section of the layer with high permeability) while the period of reaching the maximum values (curve stabilisation level) is longer, is interpreted as a gradual saturation of the pore space of the productive layer with formation water. The course of the derivative curve of the water exponent is similar, being parallel to the course of the ratio curve;

- Cone flow, characterised by a slow increase in the value of the water ratio with a simultaneous decrease in the value of its derivative.

This article presents an assessment of the formation water breakthrough mechanism for four out of eight analysed wells: J-5K, J-8K, P-6 and Z-1K. Apart from using the graphs of the history of the WGR and its derivative (WGR') change in individual wells, the daily history of gas and formation water production was also analysed. Many professionals agree that diagnostic plots cannot be the only basis for determining the water breakthrough mechanism [29]. The method of computer simulations has shown that in the case of multilayer formations, there may be situations in which cone water inflow can be confused with multilayer channel inflow $[29,31]$. In the analysed cases, it was assumed that the inflow of formation water to the well is not in the form of a 3D cone, which results directly from the lithology of the reservoir intervals in the layered autochthonous Miocene deposits in completed wells (with the exception of the Z-1K well). They are mostly thin-layer deposits, in which the thickness of individual layers with different lithology rarely exceeds $30 \mathrm{~cm}$.

As already mentioned in the assessment of the water breakthrough mechanism, in addition to the diagnostic plots, the history of gas and water extraction was also used, assuming both graphs with identical periods of operation in a logarithmic system. This made it possible to easily link the changes in the diagnostic plots with the changes in the production history of the well. The analysis of diagnostic plots in order to determine the water breakthrough mechanism is not always an easy matter and does not always give unambiguous, indisputable results. First of all, the required situation is such that no well/reservoir interventions take place in the analysed period of time. Only data included in the range of the so-called "diagnostic window" is included, i.e., the stage of production in which according to the operator's declaration, no changes were made to the method of exploitation of the interpreted formation horizon (Figure 2). The diagnostic plots shown in Figures 3-6 were plotted for the entire extraction period, ignoring the first hundred days of operation. Data from that period have practically no diagnostic value. This made the graphs more readable for points of significant change in the water ratio and its derivative of between the 800th and 1000th day of production, due to the specific nature of the distribution of values on the axes of the graph provided in a logarithmic scale.

The J-5K well

In the J-5K well, a $17 \mathrm{~m}$ long profile fragment was perforated. The analysis of the WGR chart (Figure 3a) shows that in the initial period of the well's operation, the value of the water exponent remained constant (on average about $40 \mathrm{~g} / \mathrm{m}^{3}$ ), which is characteristic of the layered flow of formation water. A significant increase in the ratio was recorded at around the 800th day of operation, which should be interpreted as an increase in phase permeability for brine. As production continued, no change in the trend of the WGR curve was observed - the last analysed point shows a value of approximately $490 \mathrm{~g} / \mathrm{m}^{3}$. The course of the curve of the water ratio derivative is parallel to the WGR curve almost throughout the entire analysed period of production. A slight decrease in the presented 
values takes place from the moment of the increase in the value of the WGR (800th day of the well's operation). The chronological summary of the production curves indicates that after the accompanying rapid increase in the production of formation water, the increase in the amount of exploited gas was only temporary (Figure 3b). Despite the subsequent decline in gas production, the trend in the amount of produced brine did not change. On the basis of the presented data, it should be concluded that the nature of the inflow of formation water to the J-5K well changed from layered to channel.

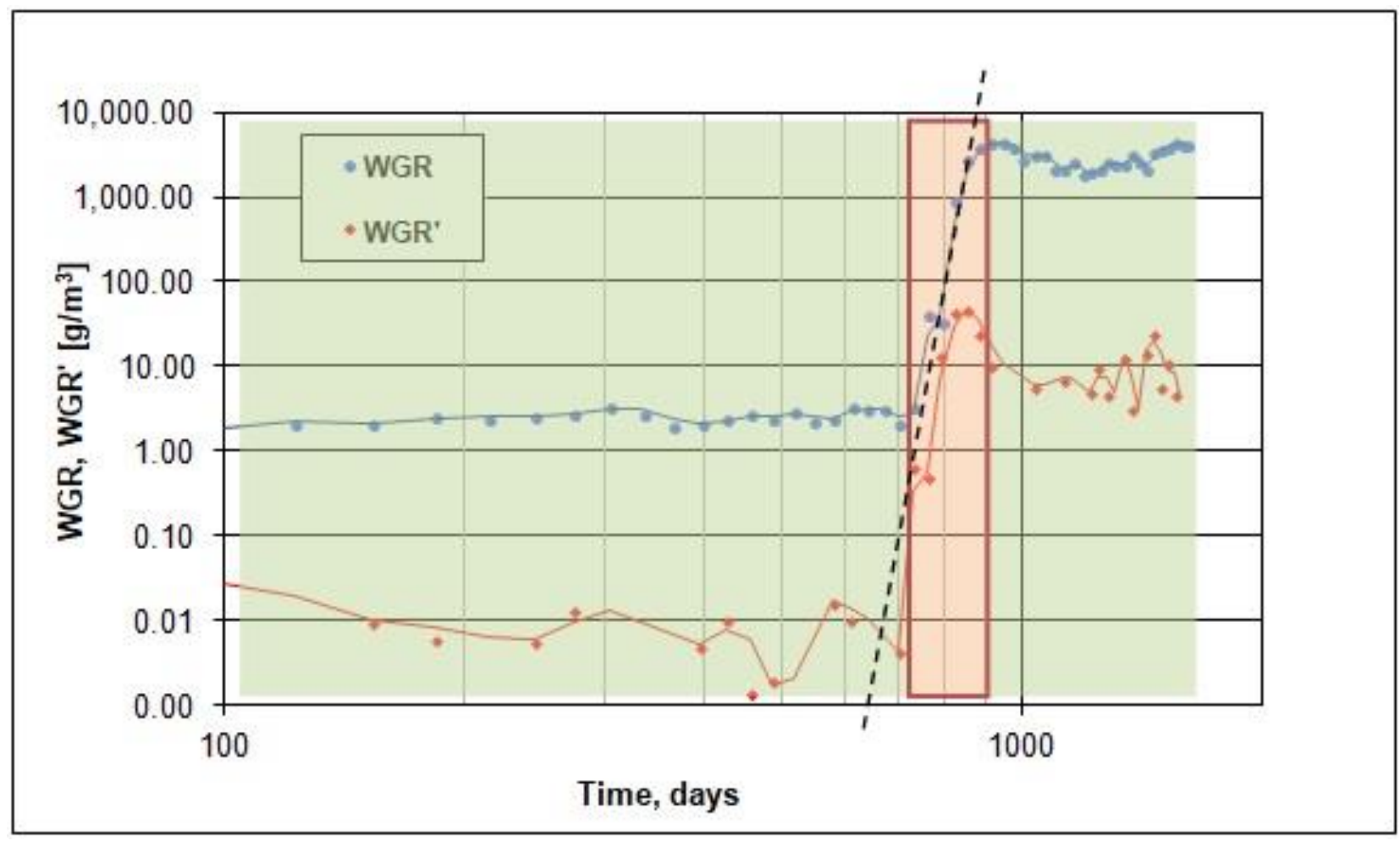

Figure 2. The diagnostic window technique for the assessment of the water breakthrough mechanism to the well.

The J-8K well

The J-8K well was perforated with two intervals $(12 \mathrm{~m}+6 \mathrm{~m})$. In the initial years of operation, the trajectory of the WGR history plot (Figure 4a) remained at a constant and low level, i.e., not exceeding a few $\mathrm{g} / \mathrm{m}^{3}$. After approximately 800 days of the well's production, the beginning of a slow but systematic increase in the WGR was recorded. With the ratio equal to about $10 \mathrm{~g} / \mathrm{m}^{3}$, after about 2000 days of extraction, a sharp 10-fold increase in the WGR to about $100 \mathrm{~g} / \mathrm{m}^{3}$ was recorded. The next period was characterised by a continued, but at a much slower pace, increase in the WGR until it temporarily stabilised at a level of about $320 \mathrm{~g} / \mathrm{m}^{3}$. After this stage, another increase in the WGR was noted-the available data indicate the maximum recorded value of the exponent ratio to $676 \mathrm{~g} / \mathrm{m}^{3}$. The curve of the WGR derivative is characterised by a parallel, with a slight downward tendency, course up to about the 800th day of production. After this period, the WGR' curve increased-The course of both curves is parallel. A comparison of the production curve with the WGR and WGR' graphs indicates the beginning of the decrease in gas production when the WGR increase begins (800th day of operation). The temporary increase in gas production was preceded by a sharp increase in the share of formation water in the total volume of the exploited media (Figure $4 \mathrm{~b}$ ). Despite another decline in production, no reduction in water production was recorded, but on the contrary, its quantity increased dramatically. On the basis of the presented data, mainly the curves of the water ratio and its derivative, it is possible to indicate a change in the nature of the water inflow to channel inflow. The presented and described increases in WGR correspond to the commencement of inflow of 
formation water from subsequent layers and are characteristic of multilayer channelling. The course of changes in the water ratio and its derivative from the moment when the ratio value exceeded $10 \mathrm{~g} / \mathrm{m}^{3}$ is very similar to the results of numerical simulations obtained by Seright [32], when successive layers separated by impermeable barriers were flooded. This is a very favourable situation for WSO treatments because the probability of cross flows is minimal [32].

a)

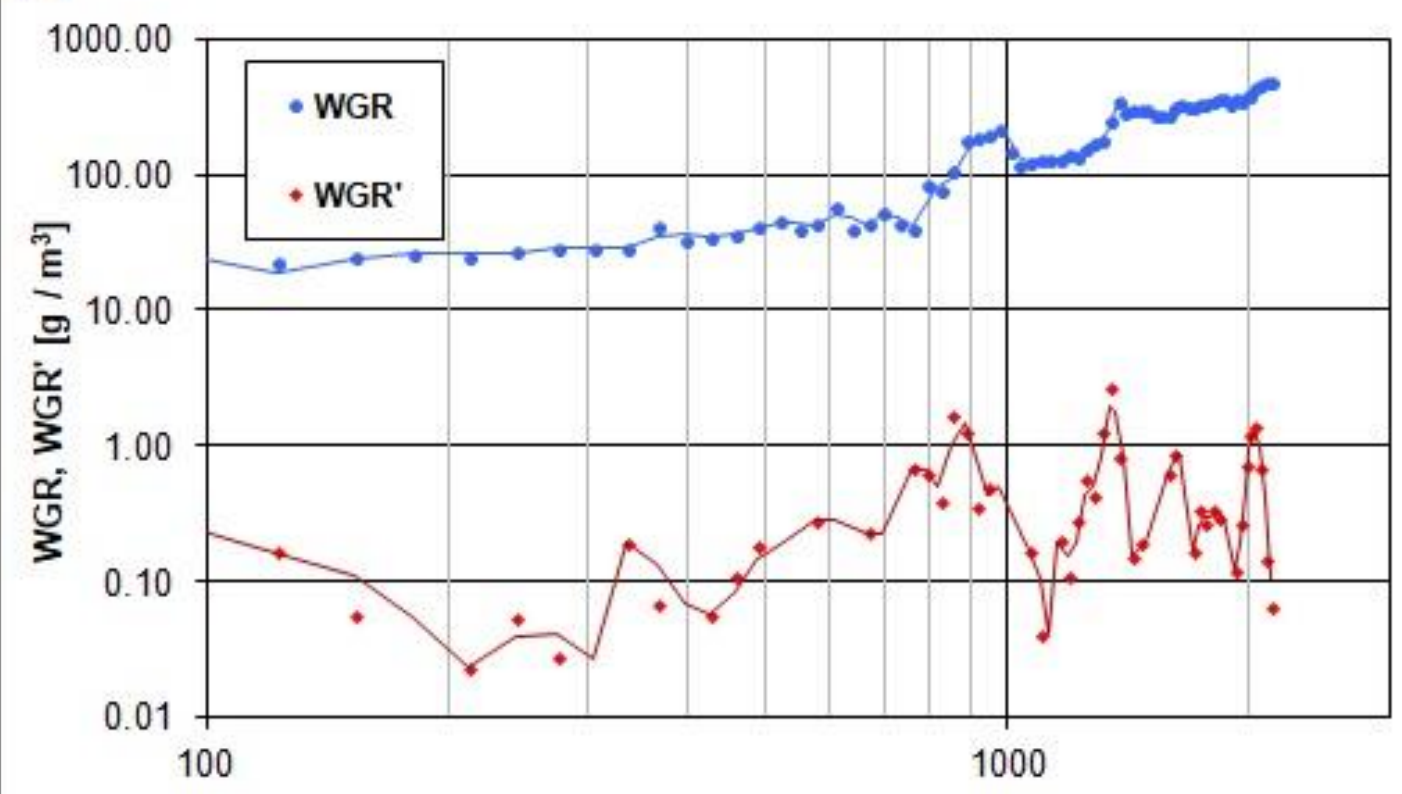

Time, days

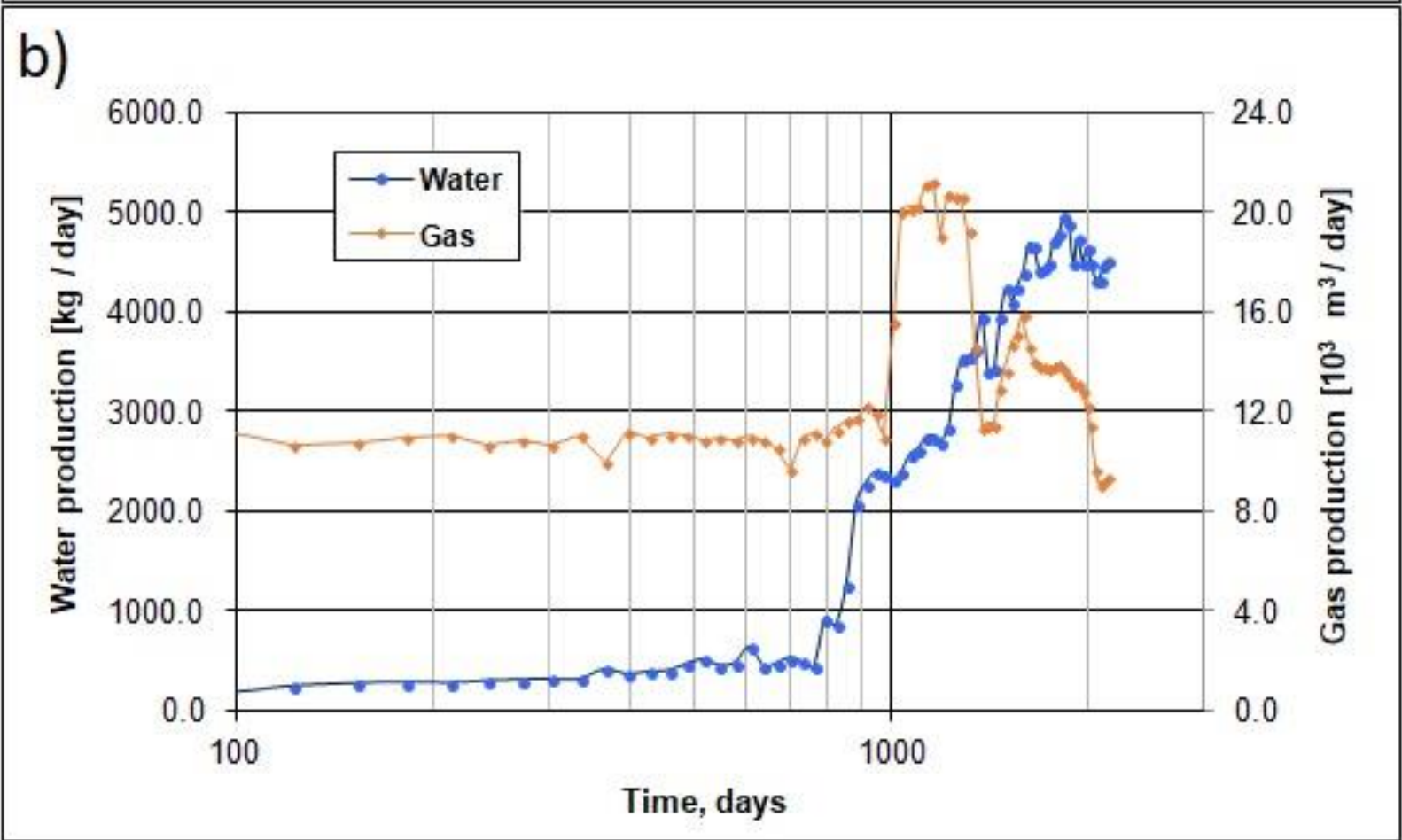

Figure 3. Changes in the WGR and its derivative over time (a) and the history of gas and formation water extraction (b) for the J-5K well. 
a)

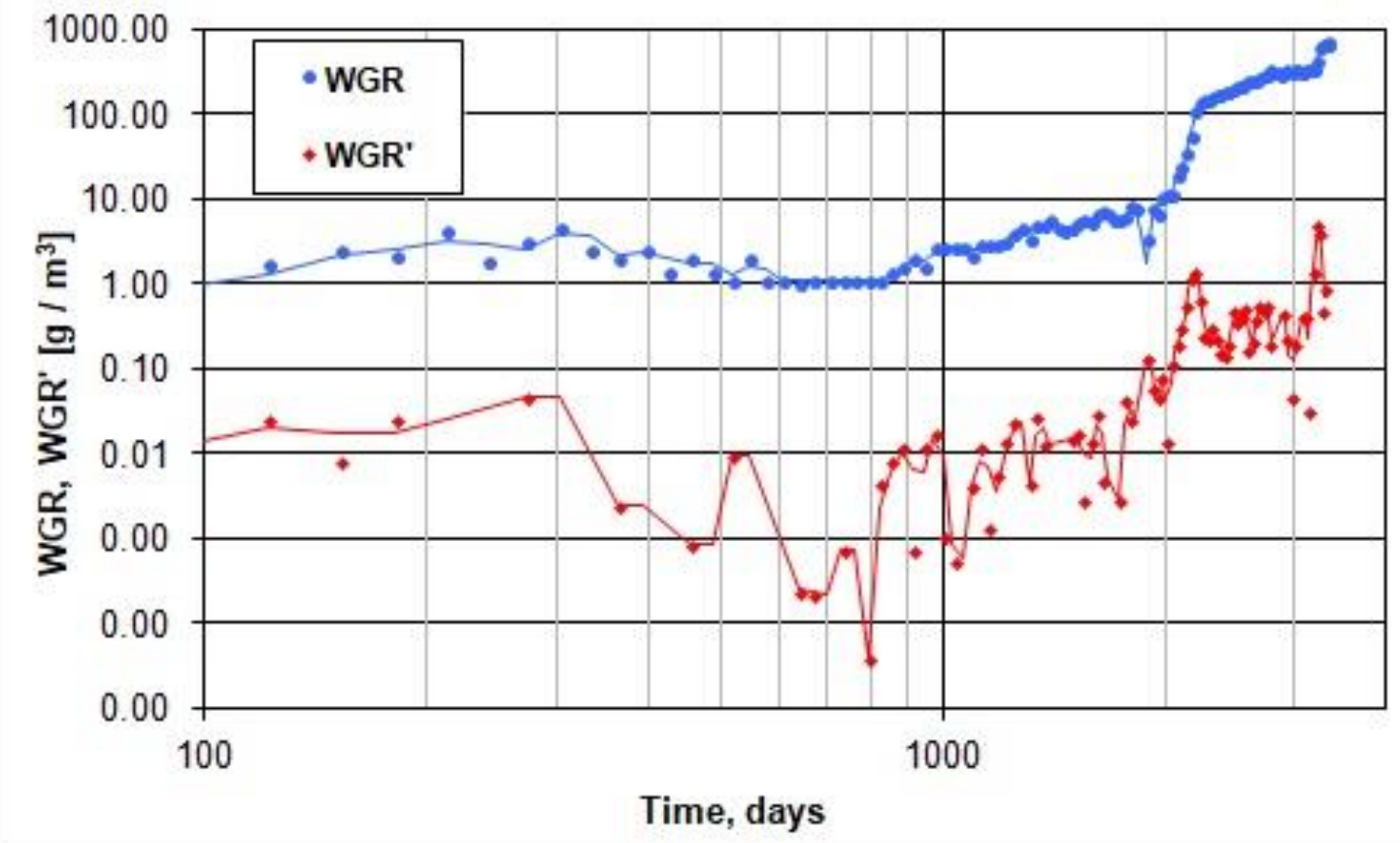

b)

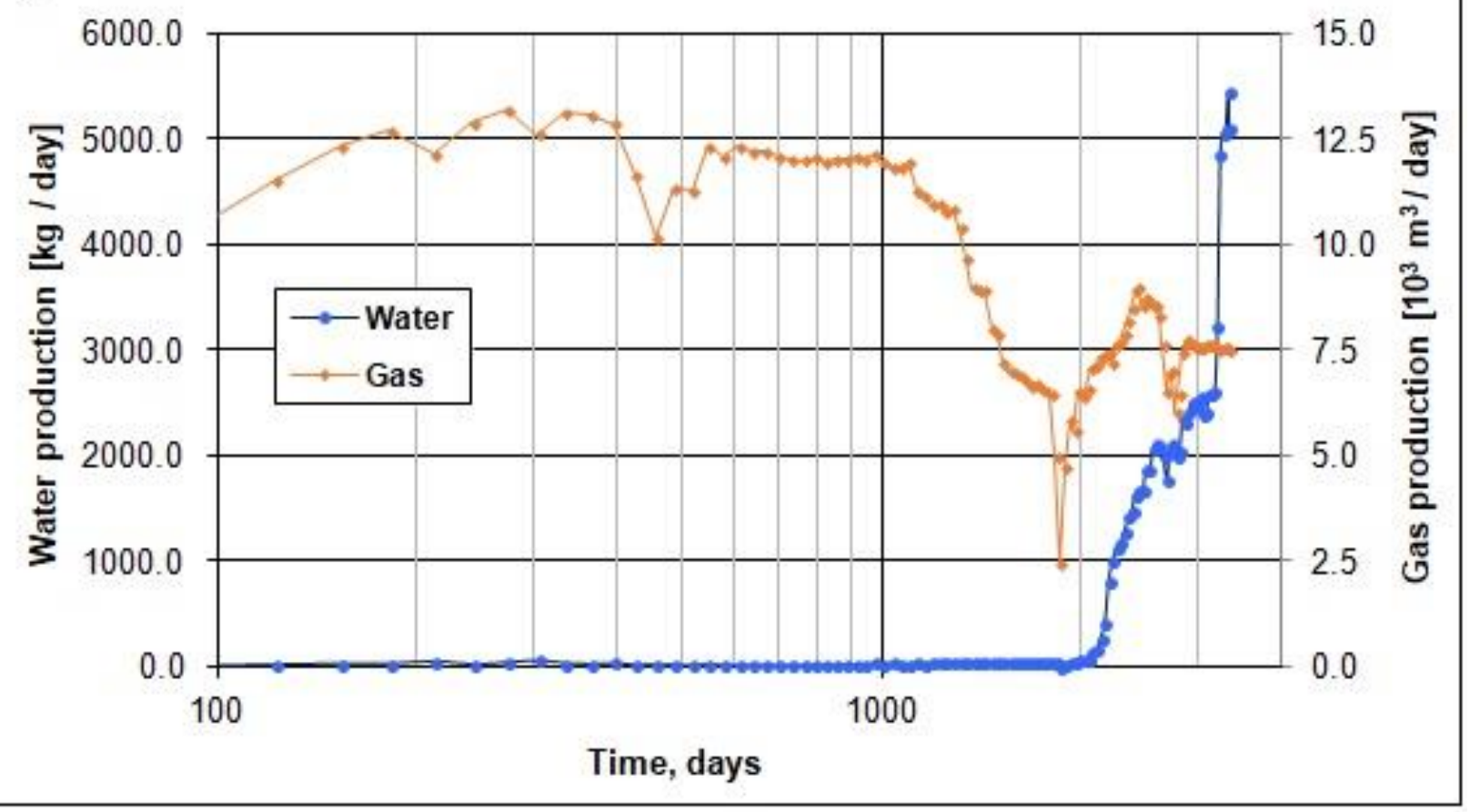

Figure 4. Changes in the WGR and its derivative over time (a) and the history of gas and formation water extraction (b) for the J-8K well. 
a)

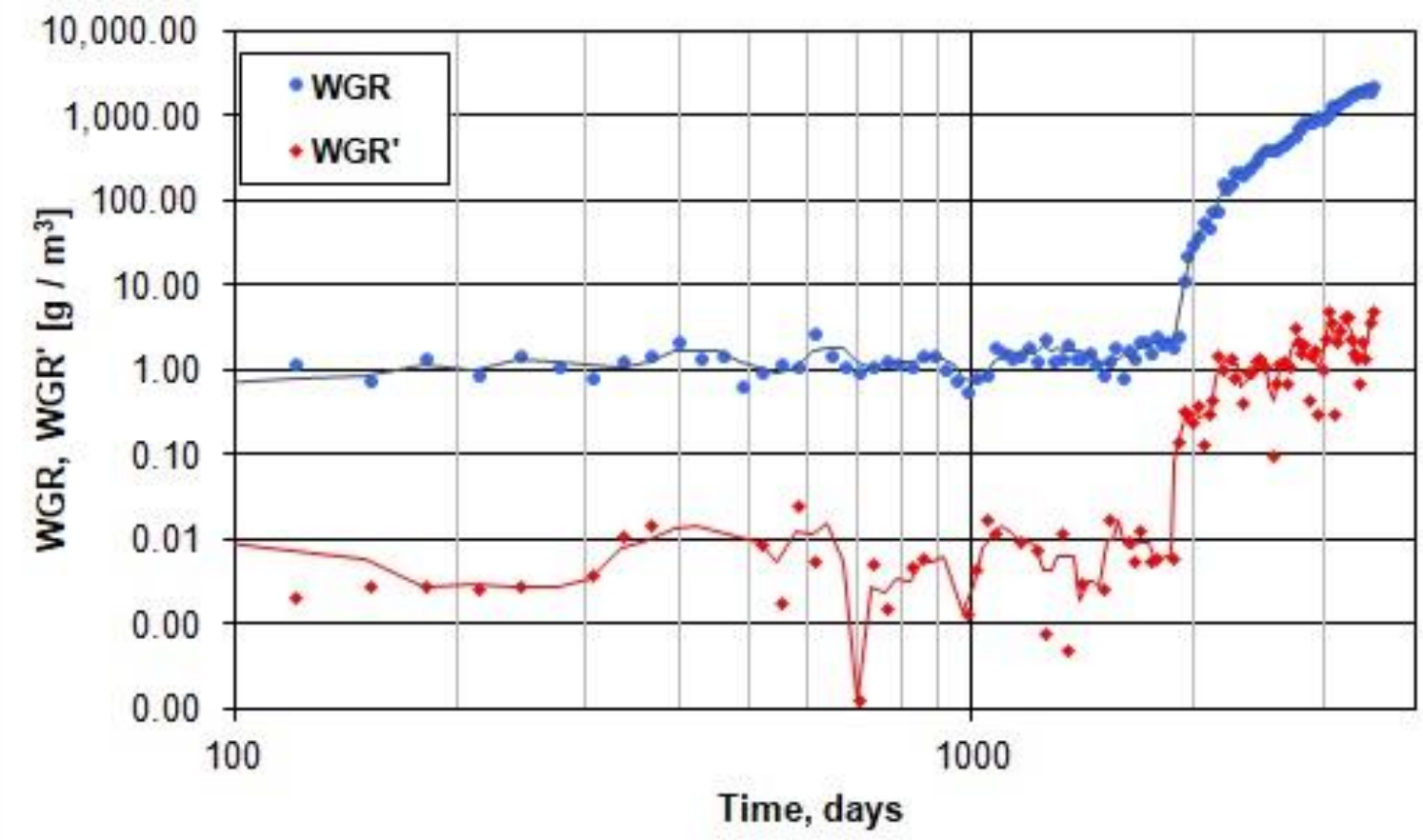

b)

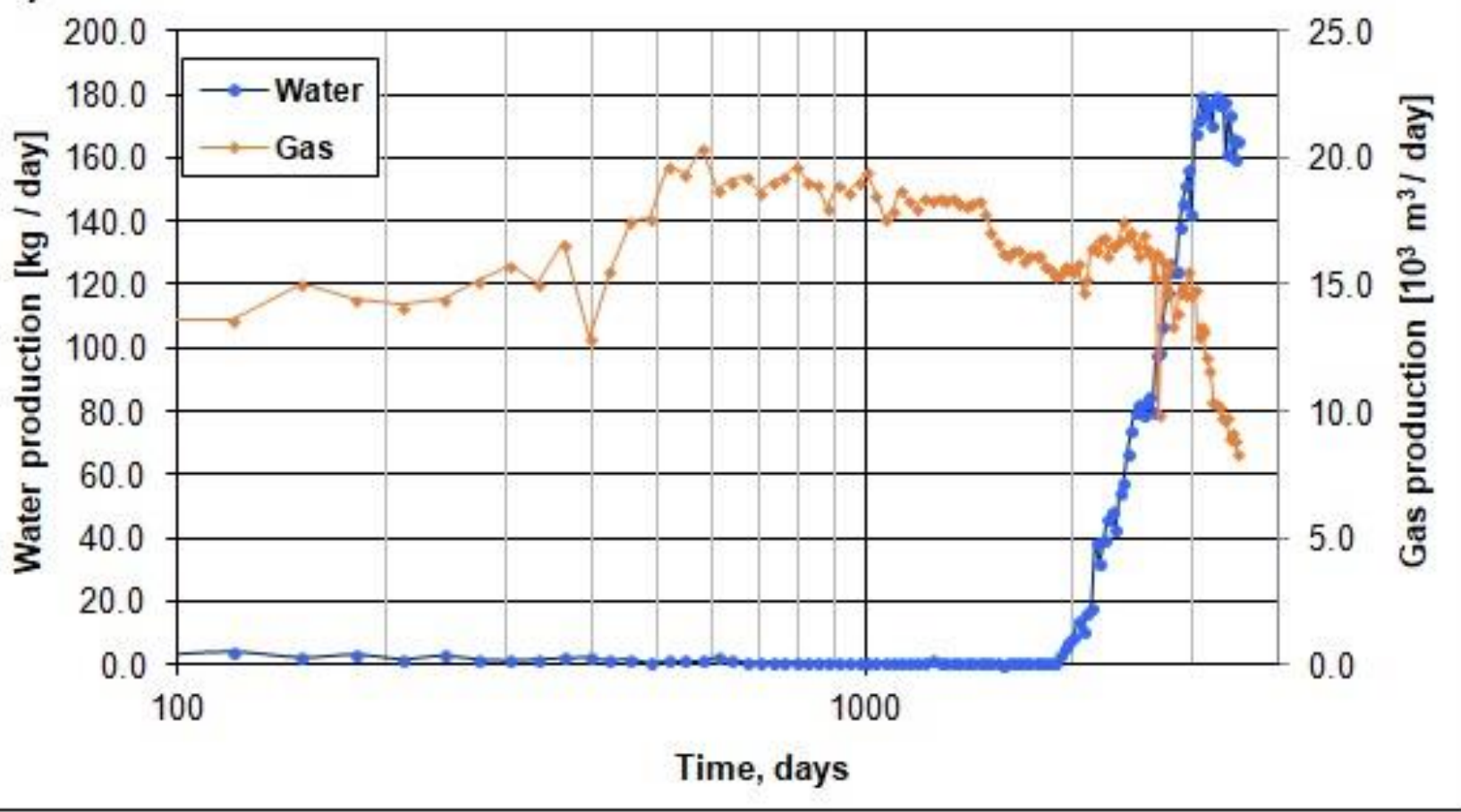

Figure 5. Changes in the WGR and its derivative over time (a) and the history of gas and formation water extraction (b) for the P-6 well. 
a)

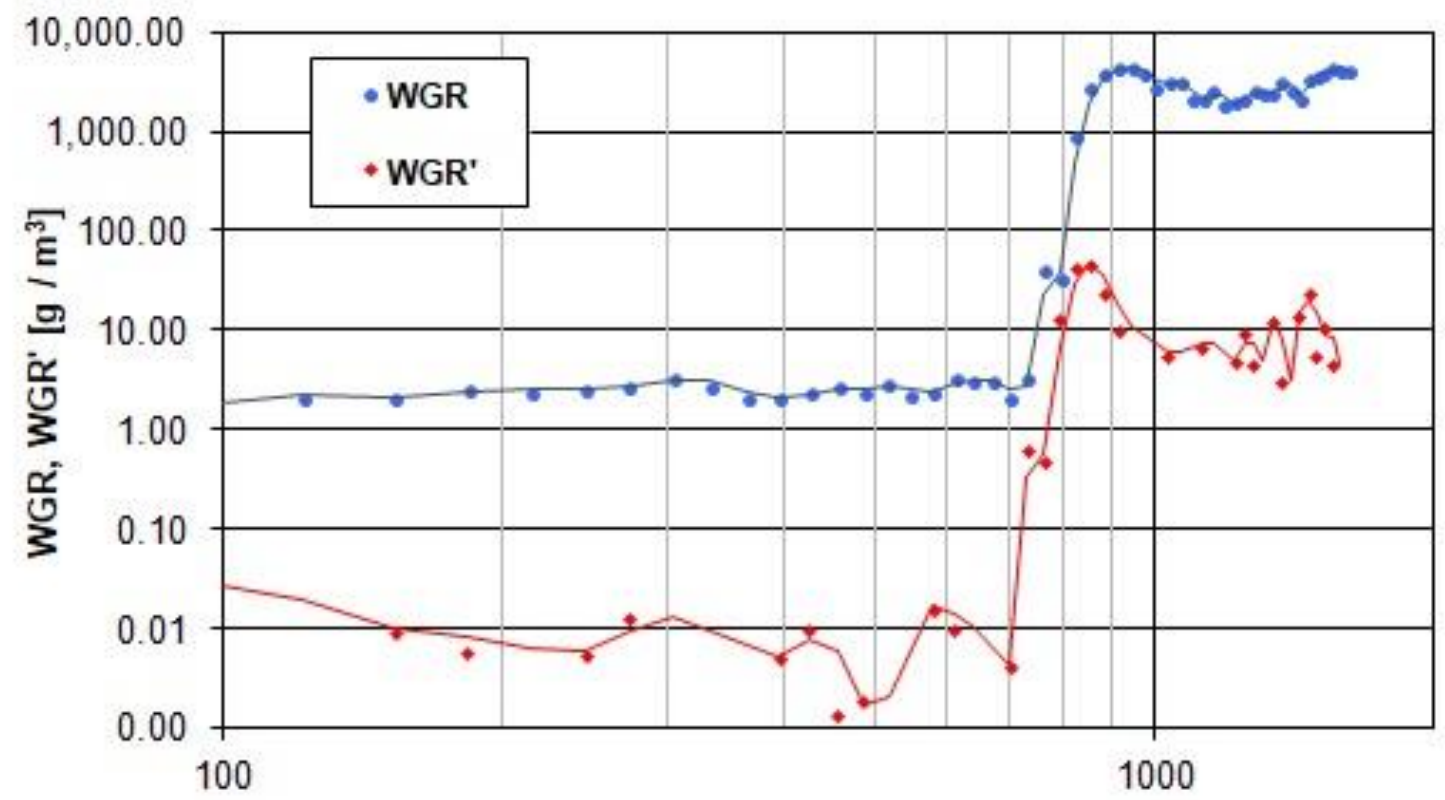

Time, days

b)

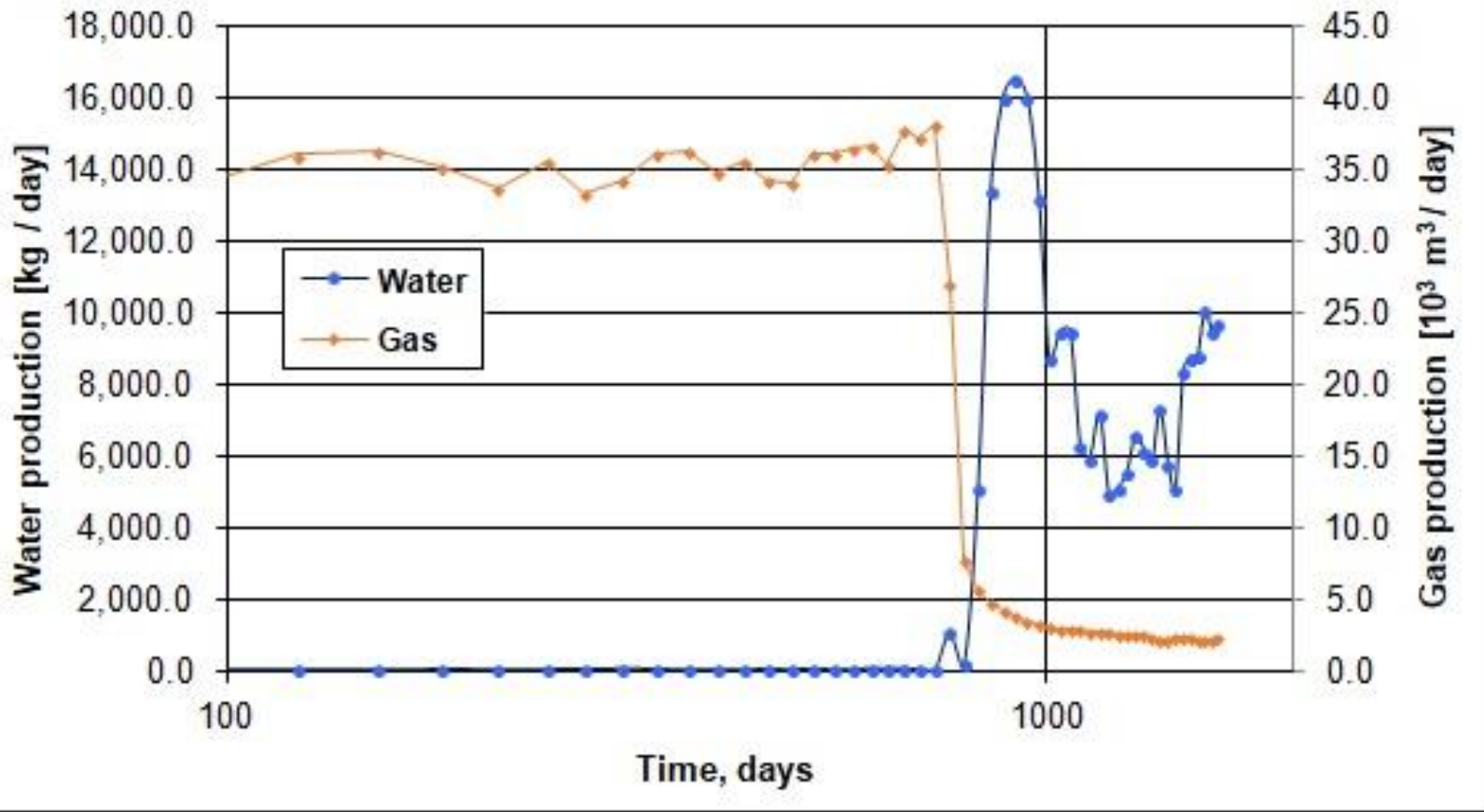

Figure 6. Changes in the WGR and its derivative over time (a) and the history of gas and formation water extraction (b) for the $\mathrm{Z}-1 \mathrm{~K}$ well.

The P-6 well

Two intervals of $18 \mathrm{~m}$ and $5 \mathrm{~m}$ were completed for production through the P-6 well. Based on the trajectory of the determined curves (Figure 5a,b), it is clear that in the first years of the well's production (up to about the 2000th day), the exploitation was carried out with a very low water ratio, with the level of condensation water not exceeding $3 \mathrm{~g} / \mathrm{m}^{3}$. The analysed period in the case of the derivative of the water ratio was also characterised 
by a constant and parallel course of the WGR curve. The increase in the phase permeability of reservoir rocks to the formation water is characterised by a sudden and rapid increase in the water ratio. During about 1500 days of production, the WGR increased to a value of about $2300 \mathrm{~g} / \mathrm{m}^{3}$, and the WGR' curve is characterised by an analogous and almost parallel course (Figure 5a). Changes in the gas and formation water production curves fully correlate with the changes in the ratio and its derivative. The increase in the production of formation water very quickly manifests itself in the decreasing volume of the exploited gas. The P-6 well is a typical example of a channel mechanism for inflow of formation water to a production well.

The Z-1K well

The Z-1K well provides the production horizon with an $18 \mathrm{~m}$ long perforation. The analysis of data from the determined curves (Figure 6a) indicates a constant and low level of the water ratio, not exceeding $4 \mathrm{~g} / \mathrm{m}^{3}$ up to about the 730th day of operation. During this period, based on the analysis of the course of the water ratio derivative, it should be concluded that there is a conical mechanism of the inflow of formation water. The water cone increases vertically and radially, thereby increasing the water saturation in its zone. In the next stage, there is a sudden and rapid increase in the WGR value to about $4000 \mathrm{~g} / \mathrm{m}^{3}$, followed by an almost immediate stabilisation of the ratio at a similar level. The course of the WGR' curve for the growth period is parallel to the course of the water ratio curve. The information contained in the curves of the production of formation water and gas confirm a significant change in the amount of gas produced when the volume of exploited formation water increases (Figure $6 \mathrm{~b}$ ). This nature of the course of changes in the value of the water ratio clearly indicates the inflow of water to the well through a fracture or behind the pipe. Based only on the above data, it is not possible to clearly determine which of these mechanisms occurred in the $\mathrm{Z}-1 \mathrm{~K}$ well.

\section{The Use of Well Logging Data to Estimate the Permeability Profile of the Reservoir Horizons in Production Wells}

The problem of estimating the permeability of porous materials has a long research history, dating back to the beginning of the 20th century. Of fundamental importance are the theoretical works by Kozeny [33] and Carman [34,35], which allowed for the development of a very general Kozeny-Carman (KC) formula for the calculation of permeability, linking many structural and textual parameters of the rock medium with the parameters of the migrating fluid. In practical terms, this approach is difficult to apply due to the general lack of information about the values of specific parameters, and especially their effective values in the case of polymineral media with a complex system of double porosity. At the same time, empirical models developed for a specific research area were developed based on macroscopic parameters determined from drill core samples, including: porosity $(\varphi)$, irreducible water content $\left(S_{w i}\right)$, capillary water content $\left(S_{\text {wirr }}\right)$ and electrical parameters. Models: Tixier [36], Timur [37], Coates and Dumanoir [38] and Coates [39] are useful tools for the continuous estimation of changes in rock medium permeability along the well profile. However, the cited solutions require each time to take into account the specificity of the studied region and the application of the procedure of calibrating the results on representative data for the current analysed rock formations.

As a part of the project to select the optimal well for the WSO treatment, the most useful approach was the approach using the existing quantitative solutions of clay mineral content $\left(V_{i l}\right)$, mineral composition $\left(V_{m \mathrm{i}}\right)$, porosity $(P H I)$ and saturation $\left(S_{w}\right)$, and available geophysical profiling of natural potentials $(S P)$, diameter $(C A L I)$ and nominal diameter $(B S M)$. The developed methodology integrates the qualitative approach, based on the analysis of anomalies registered by individual logs and their mutual relations, with a purely quantitative approach based on the Zawisza model developed for Polish conditions [40]. For obvious reasons, such an approach is needed only in causes when the Production $\log (\mathrm{PL})$ measurements are impossible to perform due to technical or financial reasons, 
because the interpretation of PL would significantly help in the selection of a well for the planned treatment.

\subsection{Assessment of Relative Changes in Permeability—Methodological Aspects}

The methodology for determining the permeable and impermeable zones was based on the qualitative analysis of profiling the diameter in relation to the nominal diameter. The presence of permeable zones is manifested by the presence of a narrowing of the diameter, i.e., the appearance of the so-called mud cake, which manifests its presence in the zones of intensive filtration of the drilling mud deep into the rock mass. Thus, a criterion can be constructed:

$C A L I \leq B S M-$ potential permeable zones;

$C A L I>B S M-$ potential sealing zones.

The above criterion is rather of a qualitative nature and cannot be used alone except where no other option is available.

The second possibility is a strict quantitative interpretative approach based on the absolute permeability estimation according to the Zawisza model. This model allows the calculation of the irreducible water content (Swi) according to Formula (1) and the absolute permeability according to Formula (2):

$$
\begin{gathered}
S w i=V i 1^{a}(1-\varphi)^{b} \\
K z a w=A \varphi^{c}(1-S w i)^{d}
\end{gathered}
$$

where:

$V_{i l}$-volumetric content of clay minerals;

$\varphi$-porosity;

$A, a, b, c, d-$ calibration constants.

The calibration constants in the above equations are determined each time for the region and formation in which the estimation is carried out and modified to best reflect the trends of changes in permeability in the available laboratory tests of drill cores, or the average values of this parameter determined on the basis of data from performed well tests.

The results of the permeability estimation allow the definition of another criterion of division into permeable and sealing layers, assuming the limit value $\mathrm{Kgr}=1 \mathrm{mD}$ for water inflow to the well. This condition will be as follows:

Kzaw $\geq K g r$ - potential permeable zones;

Kzaw $<$ Kgr - potential sealing zones.

The sum of the above criteria is a collective criterion and is the basis for the final division of the profile into:

$C A L I \leq B S M$ and Kzaw $\geq K g r-$ permeable zones;

$C A L I>B S M$ and Kzaw < Kgr - sealing zones.

The characteristics of the remaining parts of the profile are ambiguous in relation to the above methodological assumptions.

\subsection{Analysis Results}

The overall results of the analyses are presented in the figures below (Figures 7-10). The following columns show:

Track 1-profiling of gamma GR (API) and natural potentials $S P(\mathrm{mV})$;

Track 2-MD depth (m);

Track 3-perforation intervals;

Track 4-borehole diameter (caliper);

Track 5-results of lithological and porosity analysis;

Track 6-results of the analysis of primary saturation with formation media; 
Track 7-the results of the absolute permeability estimation according to the Zawisza model (Kzaw) (mD);

Track 8-analysis of permeable and sealing zones according to the collective criterion; Track 9-MD depth (m).

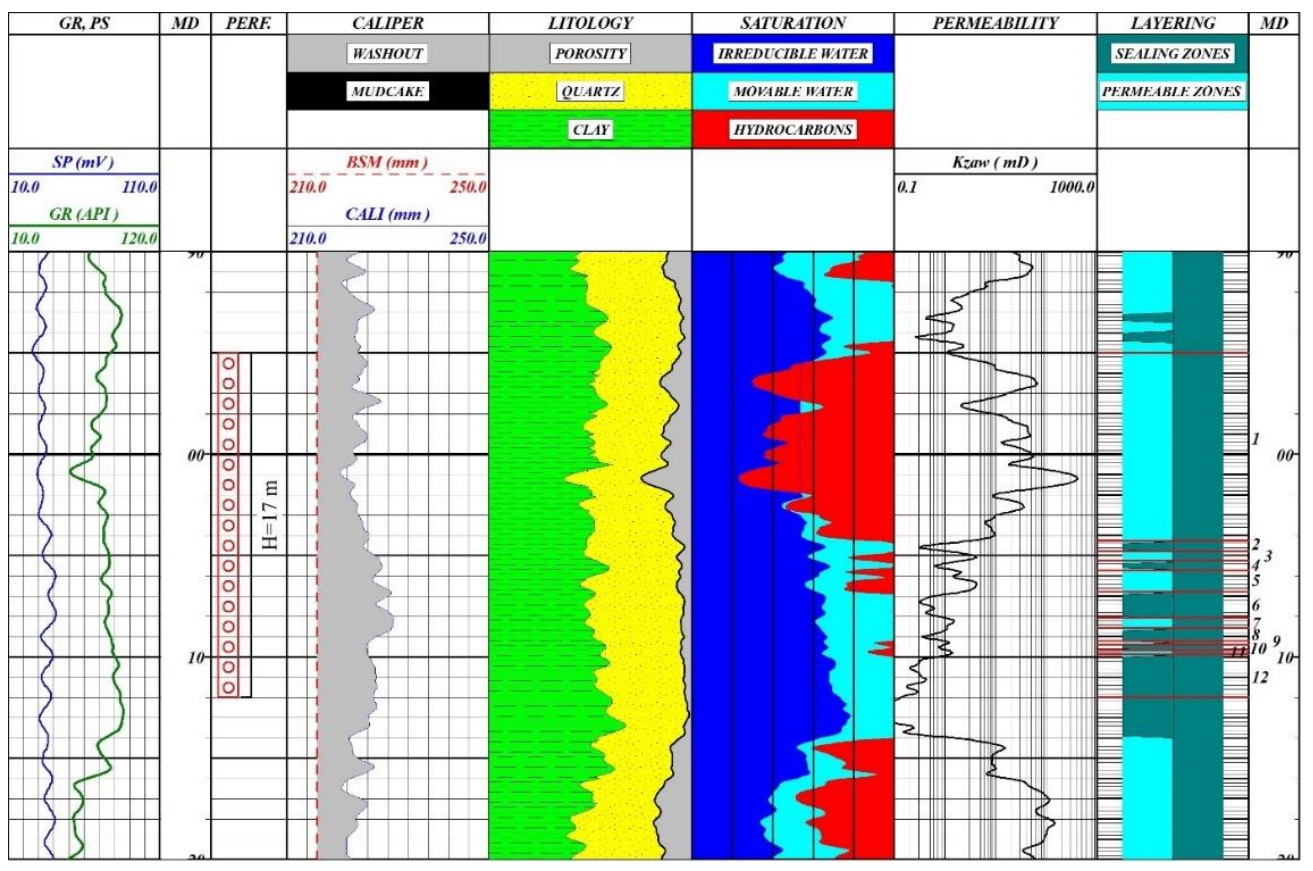

Figure 7. Results of the interpretation of the profile of permeability changes within the analysed perforation interval in the J-5K well.

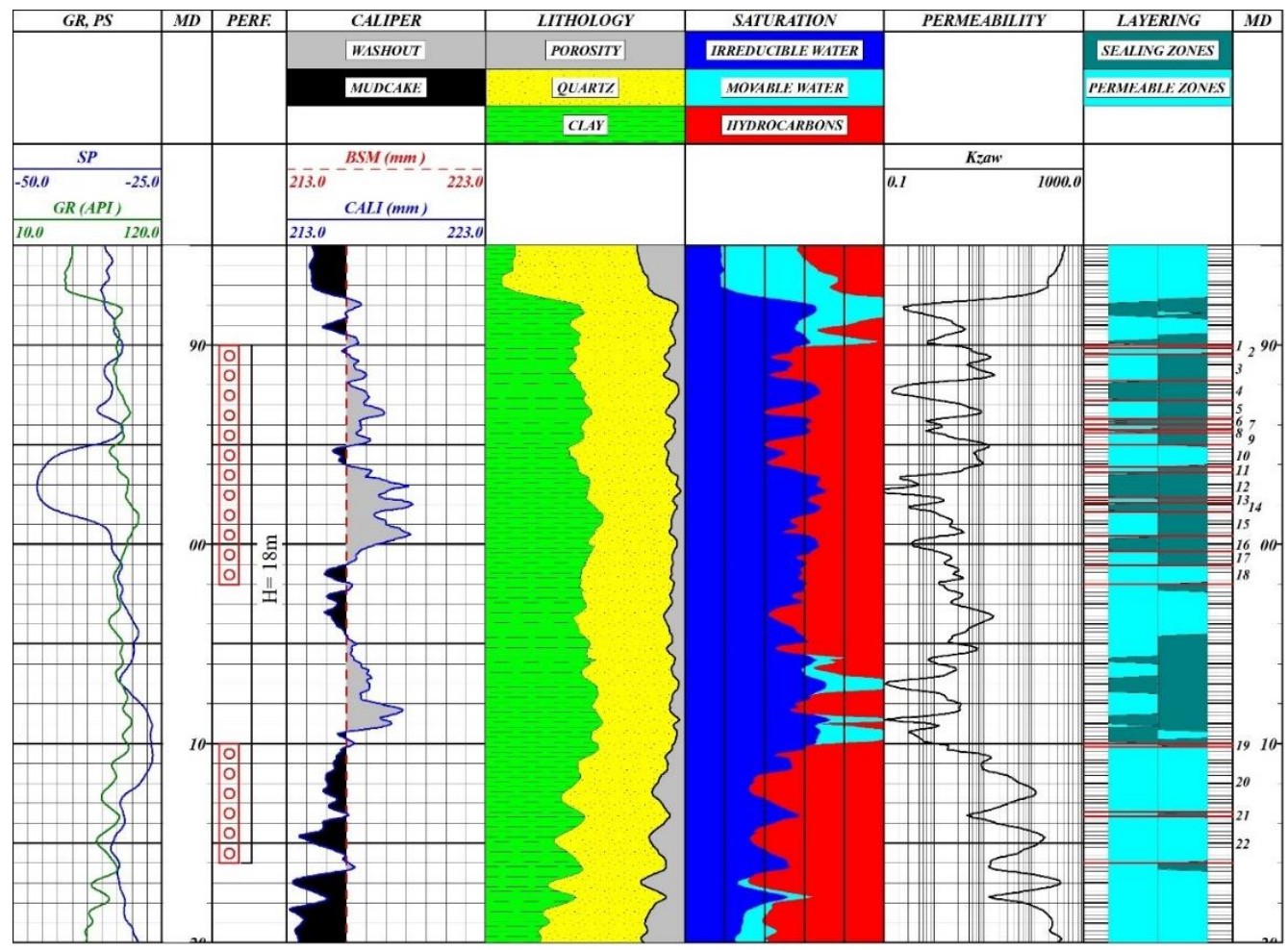

Figure 8. The results of the interpretation of the permeability change profile within the analysed perforation intervals in the J-8K well. 


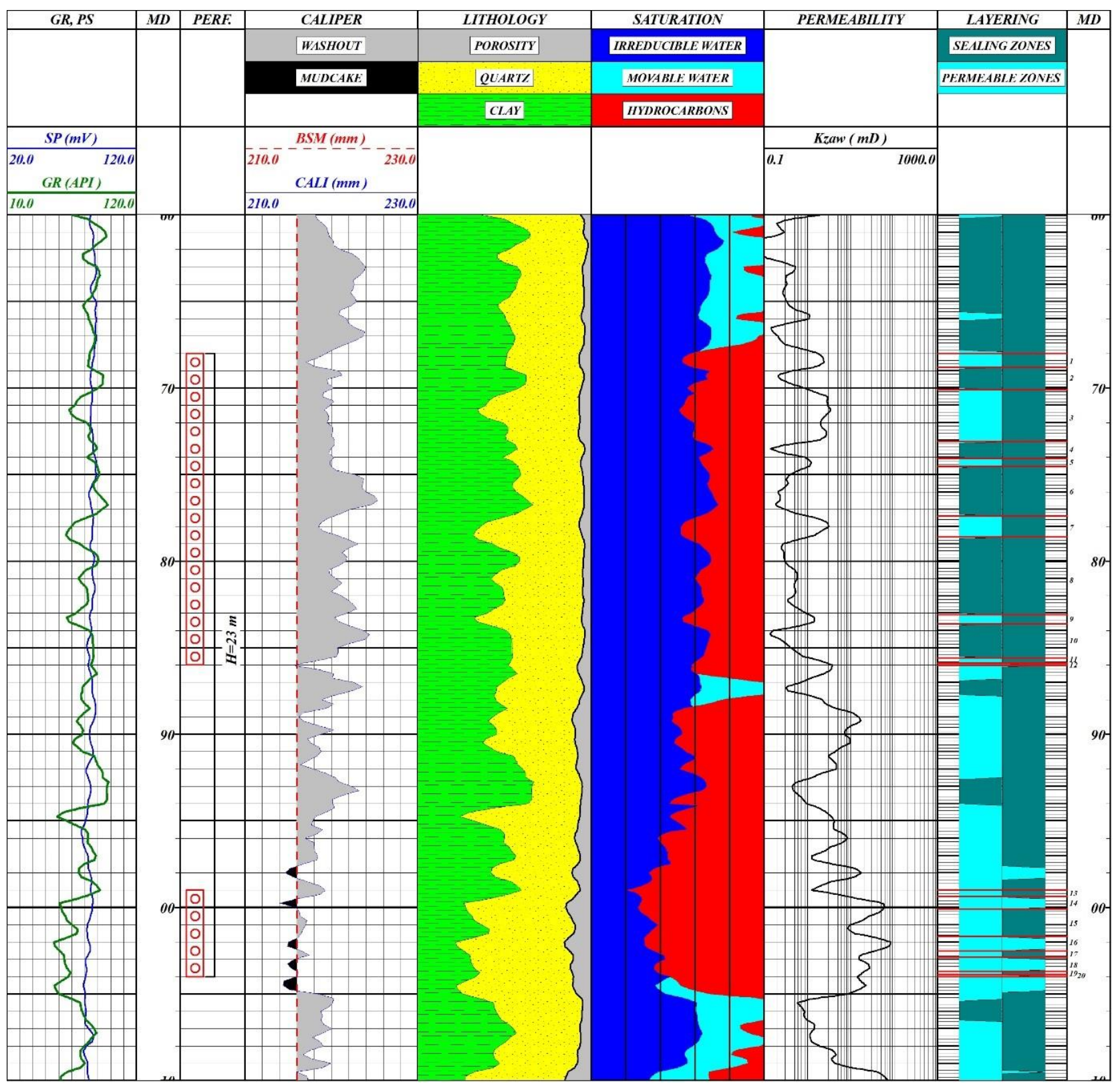

Figure 9. Results of the interpretation of the permeability changes profile within the analysed perforation intervals in the P-6 well.

The description of the results obtained for four of the analysed wells is presented below, with the emphasis on the number of interpreted layers (permeable and impermeable).

The J-5K well (Figure 7)

In the interval of the perforation providing access to the $17 \mathrm{~m}$ section of the gas horizon profile, an analysis was performed which confirmed the presence of 12 zones with variable filtration characteristics, most of them with unambiguous sealing properties, especially in the bottom part of the horizon.

The J-8K well (Figure 8)

Two perforation intervals were analysed in the J-8K well: the $12 \mathrm{~m}$ long upper interval profile is characterised by much greater diversity in terms of filtration properties. The lower perforation interval $(6 \mathrm{~m})$ almost entirely covers the unambiguously permeable zone. In total, 22 layers with different reservoir parameters were distinguished in this well. 


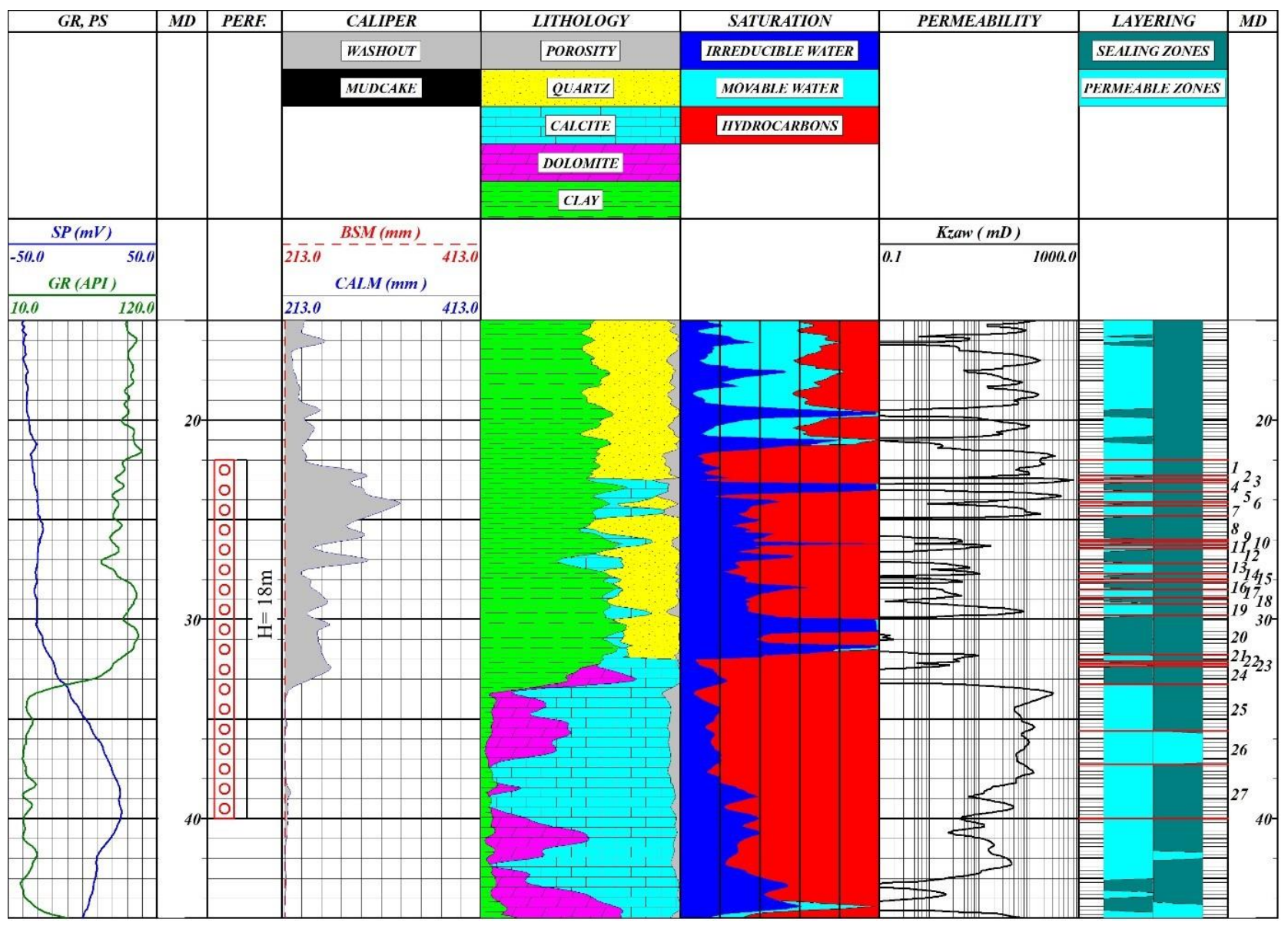

Figure 10. Results of the interpretation of the permeability changes profile within the analysed perforation interval in the Z-1K well.

The P-6 well (Figure 9)

The subject of the analysis in the P-6 well were two perforation intervals $(18 m+5 m)$ completed in one gas horizon. These two fragments of the gas horizon profile differ significantly in terms of reservoir characteristics. The lower perforation covers a fairly homogeneous sandstone complex which is practically one permeable formation zone. On the other hand, the part of the profile completed in the upper perforation is characterised by much more variety in terms of reservoir properties, with a large number of unambiguously sealing zones. In this well, it is possible to distinguish a total of 20 zones with different filtration properties.

The Z-1K well (Figure 10)

The $18 \mathrm{~m}$ long perforation, consisting of the top part of the gas horizon in the $\mathrm{Z}-1 \mathrm{~K}$ well, includes the top part of an Upper Devonian carbonate complex and the bottom part of Lower Carboniferous clastic formations, which directly translates into the two-fold nature of the interval provided. The lower part of the perforation interval (carbonate rocks) is a fairly homogeneous zone in terms of filtration properties, while the clastic formations lying above are composed of a large number of layers which are unambiguously and ambiguously sealing. The performed interpretation allowed for distinguishing 27 zones with different filtration properties.

\subsection{Ranking of Wells for the Performance of the WSO Treatment Based on the Interpretation of Well Logging Data}

For the purpose of performing a ranking of wells for comparative purposes, a quantitative parameter the called "perforation overlayering index" $(U)\left(\mathrm{m}^{-1}\right)$ was defined, which 
specifies the average number of distinguished layers in relation to a running metre of perforation made in the well. The calculations were carried out according to the following Equation (3)

$$
U=\frac{w}{H}\left[\mathrm{~m}^{-1}\right]
$$

where:

$w$-total number of recognised layers (both unambiguous and ambiguous);

$H$-total number of metres of perforation made in the well $(\mathrm{m})$.

The introduced $U$ parameter determines the diversification of the formation in terms of the number of layers with different filtration properties. It was found that the highest values of this parameter would be the most beneficial in terms of performing WSO procedures. Table 1 summarises the systematised results of the $U$ parameter estimation for the abovementioned wells. When analysing the compiled values of the $U$ parameter for clastic rocks, the first place in the ranking was achieved by the J-8K well $(U=1.22)$, the second by P-6 $(U=0.87)$ and then $\mathrm{J}-5 \mathrm{~K}(U=0.7)$. For the $\mathrm{Z}-1 \mathrm{~K}$ well, representing carbonate rocks, the $U$ parameter value was 1.5 .

Table 1. Ranking of the wells for the performance of the WSO treatment based on the interpretation of permeability.

\begin{tabular}{cccc}
\hline Well & $\boldsymbol{w}$ & $\boldsymbol{H}(\mathbf{m})$ & $U=\boldsymbol{w} / \mathbf{H}\left(\mathbf{m}^{-\mathbf{1}}\right)$ \\
\hline J-5k & 12 & 17 & 0.7 \\
\hline J-8k & 22 & 18 & 1.22 \\
\hline P-6 & 20 & 23 & 0.87 \\
\hline Z-1k & 27 & 18 & 1.5 \\
\hline
\end{tabular}

\section{Well Ranking Based on the Well Evaluation Card}

As part of the project, in the first stage of the ranking, eight wells from the Carpathian Foredeep and the marginal part of the Carpathians were evaluated (Figure 1). The initial selection of these wells was made by the operator. In six wells (C-2, J-5K, J-8K, J-7, P-6, $\mathrm{Z}-74)$, gas-bearing horizons related to clastic reservoir levels in Miocene formations were selected for a possible treatment, while in the other two cases (T-3, Z-1K) gas accumulations were located in Palaeozoic carbonate rocks. The ranking of selected wells and reservoir horizons was based on the collected geological, reservoir and exploitation data, as well as a preliminary interpretation of the well logs. As part of the project, a special tool was created, which was called the Well Evaluation Card (WEC). It is a special spreadsheet created in MS Excel, which in a relatively simple technical way allows one to assess the suitability of a given gas well for water shut-off treatment on a 100-point scale. Thus, when evaluating several wells, it is possible to rank them in terms of their suitability for the treatment based on a simple criterion, i.e., the more points the well achieves, the more suited it is for the treatment. It should be emphasised that in the event of failure to meet (or lack of data) one of the so-called "critical conditions" (included in the first part of the card), a well is disqualified as a candidate for water shut off. The interface of this tool is relatively simple. It has been constructed in such a way as to be as easy as possible to use for the user, and at the same time to minimise the possibility of making mistakes by the user, enabling multi-stage evaluation of individual criteria through the use of advanced MS Excel functions.

The category of "critical conditions" necessary to be met includes: water production mechanism, the length of the perforation interval (not more than $50 \mathrm{~m}$ ), water salinity and the formation temperature. The second group of scored criteria is "other conditions", which include: geometry of the water inflow, presence or absence of impermeable barriers, lithological profile differentiation, type of reservoir, water saturation coefficient, thickness of the gas-bearing horizon and effective permeability. The third group of criteria (not 
scored) is "supplementary information", which is intended to facilitate the possible decision regarding the validity of the procedure in the well, if the aforementioned scoring criteria are met. The third group of criteria includes parameters, such as field pressure, water-gas ratio, recovery efficiency, porosity, possibility of acid treatment, possibility of increasing the pressure drawdown and additional tests performed.

From among the eight analysed wells, the four wells with the highest scores were selected in the first stage based on the criteria and scores resulting from the WEC: C-2 (81.3), J-5K (76.6), J-8K (76.6) and P-6 (73.0). The T-3 (53.4) and Z-1K (50.0) wells had the lowest scores, mainly due to the unfavourable mechanism of water inflow through a fracture or behind pipe.

In the next stage of the ranking, only the four above-mentioned wells, which obtained the highest number of points in the previous stage, were considered. The detailed data contained in the geological documentation of the gas fields and the detailed results of the interpretation of the well logs were taken into account. The analysis of these data allowed for obtaining more detailed information on the lithological diversity and the spread of reservoir properties (especially permeability) in the vertical profiles of the selected formation horizons. In three of the four analysed wells (J-5K, J-8K and P-6), the profiles of the interpreted reservoir horizons are characterised by a clear lithological differentiation and the presence of impermeable inserts of fine-clastic rocks within them. In the fourth case (C-2), the reservoir horizons are characterised by lower lithological diversity, and above all by good reservoir properties in the entire intervals completed by pipe perforations. Such horizons should not be taken into account for the test procedure of limiting water production, due to the possibility of cross flows resulting from the homogeneity of the layers completed by perforations. In the final ranking, carried out on the basis of updated information obtained from research and analyses carried out during the project implementation, two wells were considered the most optimal in terms of the planned treatment to reduce water production: P-6 (73.0) and J-8K (68.2). In both of these wells, the reservoir horizons are completed by two perforation intervals with different properties: the upper intervals are characterised by a much greater lithological variability and differentiation of reservoir parameters (within them, a number of permeable and impermeable zones can be distinguished), while the intervals of lower perforations constitute zones with good permeability (Figures 8 and 9).

\section{Discussion}

The volume of natural gas consumption in Poland is growing at a much faster pace than production from gas fields that are newly connected for exploitation. An important issue is therefore the idea of implementing secondary methods aimed at increasing the depletion rate over the largest possible area of the field. However, it should be remembered that in the case of small, highly depleted formations, expenses and investment expenditures (OPEX and CAPEX) may exceed the expected returns. In such cases, a more logical decision may be to implement one of the possible methods of improving exploitation efficiency, i.e., the implementation of technologies aimed at the immediate vicinity of production or injection wells, as WSO technologies are. Technologies of this type, including the innovative RCC technology, have been successfully used in Hungary [8,10]. The first treatments performed will provide an answer to the effectiveness of this type of treatment in the Polish part of the Carpathian Foredeep. It should be emphasised that the injection of the treatment fluid into the formation is a relatively simple operation from a technical point of view. However, this type of treatment cannot be performed in every gas well, therefore an extremely important factor for determining the success of the operation is the selection of an appropriate well that meets certain criteria.

This article only discusses the issues related to the selection of wells based on broadly understood geological, reservoir and exploitation data. However, economic factors were not mentioned. Therefore, it should be emphasised that while the assessment of the technological effects of the treatment is relatively simple (by comparing the production of 
water and gas before and after the treatment), the assessment of the economic effects is not easy or unambiguous. When assessing economic aspects, many factors should be taken into account, such as the costs of sanding, the method of transporting and managing water in specific technical and legal conditions, benefits related to the possibility of continuing operation under unchanged conditions of pressure, etc.

Many authors $[1,5,12,41-44]$ agree that one of the most important criteria for assessing wells is the interpretation of the history of changes in the water ratio and its derivative, leading to the identification of the well water breakthrough mechanism. Correct identification of the water breakthrough mechanism allows the rejection of those wells which do not qualify for any chemical water shut-off treatment. Another important criterion, which significantly determines the possibility of performing the treatment is the vertical lithological differentiation of the profile of perforated interval. Other important criteria include:

- Formation water salinity;

- The reservoir temperature;

- Length of the perforation.

However, it is worth noting that as research and technological development progresses, perhaps new solutions will be developed and in the future some of these limitations will no longer be an obstacle to the implementation of water production reduction measures.

Based on the ranking, two wells were finally selected from the eight wells assessed for the water production limitation treatment (P-6 and J-8K). Bearing in mind the procedure of selecting and recommending wells for the possible treatment of limiting water production, it is worth noting that it prefers specific features or specific ranges of values of particular reservoir and exploitation parameters. It can be assumed that the currently proposed technology, based on working fluids prepared on the basis of microemulsions, will be suitable for gas horizons characterised by significant lithological differentiation and located mainly in the middle part of the autochthonous Miocene profile in the Carpathian Foredeep. In practice, this differentiation translates into the presence of a number of permeable and impermeable alternate layers in the profile of the gas interval completed by perforation. The lack of such impermeable barriers disqualifies the well as a candidate for the treatment. The discussed technology will certainly not be used in collectors developed in thick-bedded formations (e.g., amalgamated sandstone beds), massive formations or reservoirs located in stratigraphic traps.

In each case of an attempt to reduce water production in a gas well, it is necessary to assess such a well in terms of water breakthrough mechanisms and its verification based on the Well Evaluation Card. This will help to exclude cases where the procedure cannot be performed, or it will not bring the expected results.

In the case of horizons located in the deeper part of the Miocene profile of the Carpathian Foredeep, as well as natural gas fields located in other petroleum basins, such features as lithological variability, the degree of compaction as well as formation water salinity may be so different that the proposed technology will require significant modification.

\section{Conclusions}

Well pre-selection procedure is the first step in the selection of wells for WSO treatment. This was developed to quickly and definitively reject a well as a candidate for WSO treatment. Wells that were not rejected in the pre-selection procedure are not candidates for treatment, yet further verification is required.

In the porous formations, the lack of natural impermeable barriers in the completed interval strongly reduces the probability of WSO treatment success in a given well.

It is important to base the diagnosis on time intervals (so-called diagnostic windows) when assessing the water inflow mechanism, when the well was producing without operator intervention.

Finally, to recommend a well as a candidate for WSO treatment, it is not possible to rely only on one of the criteria, but it is necessary to analyse all available geological, formation and exploitation data for successful outcome. 
Author Contributions: Conceptualisation: S.F., A.U., M.S. and M.M.; formal analysis: S.F.; investigation and methodology: S.F., A.U., M.S. and M.M.; writing-original draft preparation: S.F., A.U., M.S. and M.M.; writing-review and editing: S.F. and A.U.; visualisation: M.S. and M.M.; supervision: S.F. and A.U. All authors have read and agreed to the published version of the manuscript.

Funding: The research leading to these results received funding from the Project titled "Procedure: well selection, water shut-off treatment scenario in gas production wells and preparing microemulsion based treatment fluid", under grant agreement No. DK-4100-190/18.

Institutional Review Board Statement: Not applicable.

Informed Consent Statement: Not applicable.

Data Availability Statement: Not applicable.

Acknowledgments: The authors express their thanks to the Polish Oil and Gas Company, PGNiG SA, Warsaw, Poland, for granting permission for the use of geological and exploitation data and consent to publish the results.

Conflicts of Interest: The authors declare no conflict of interest.

\section{References}

1. Bailey, B.; Crabtree, M.; Tyrie, J.; Elphick, J.; Kuchuk, F.; Romano, C.; Roodhart, L. The Challenge of Water Control. Oilfield Rev. 2000, 12, 30-51.

2. Veil, J.A.; Clark, C.E. Produced Water Volumes and Management Practices. In Proceedings of the SPE International Conference on Health, Safety and Environmental in Oil and Gas Exploration and Production, Rio de Janeiro, Brazil, 12-14 April 2010. [CrossRef]

3. Veil, J.A. Produced water volumes and management in 2017-An update. In Proceedings of the GWPC Annual Forum, Oklahoma City, OK, USA, 15-17 September 2019; pp. 15-17.

4. Seright, R.S.; Lane, R.H.; Sydansk, R.D. A strategy for attacking excess water production. SPE Prod. Facil. 2003, 18, 158-169. [CrossRef]

5. Lakatos, I.J.; Lakatos-Szabo, J.; Szentes, G.; Jobbik, A.; Vago, A. Application of Self-Conforming well Stimulation technology in Oil and Gas Fields-Fundamentals and Case Histories. In Proceedings of the IOR 2017-19th European Symposium on Improved Oil Recovery, Stavanger, Norway, 24-27 April 2017. [CrossRef]

6. Sydansk, R.; Seright, R.S. When and Where Relative Permeability Modification Water-Shutoff Treatments Can Be Successfully Applied. SPE Prod. Oper. 2007, 22, 236-247. [CrossRef]

7. Zaitoun, A.; Kohler, N.; Guerrini, Y. Improved Polyacrylamide Treatments for Water Control in Producing Wells. J. Pet. Technol. 1991, 43, 862-867. [CrossRef]

8. Lakatos, I.J.; Lakatos-Szabo, G.; Szentes, G.; Bodi, T.; Vago, T.; Karaffa, Z. Multifunctional Stimulation of Gas Wells Operating in Gas Cap over a Depleted oil Reservoir. In Proceedings of the SPE International Conference \& Exhibition on Formation Damage Control, Lafayette, LA, USA, 24-26 February 2016. [CrossRef]

9. Sobanova, O.B.; Fridman, G.B.; Arefyev, Y.N. Laboratory and Oil Field Testing for Application of Compositions Including Hydrocarbonsand Surfactants for Restricting Water Influx into Producing Wells. In Proceedings of the Paper Presented at the 7th European Symposiumon IOR, Moscow, Russia, 5-7 July 1993.

10. Lakatos, I.J.; Lakatos-Szabo, J.; Szentes, G.; Vago, A. Restriction of Water Production in Gas Wells by Induced Phase Inversion: Field Case Studies. In Proceedings of the SPE International Symposium and Exhibition on Formation Damage Control, Lafayette, LA, USA, 26-28 February 2014. [CrossRef]

11. Alfarge, D.K.; Wei, M.; Bai, B. Numerical simulation study of factors affecting relative permeability modification for water-shutoff treatments. Fuel 2017, 207, 226-239. [CrossRef]

12. Chan, K.S. Water Control Diagnostic Plots. In Proceedings of the SPE Annual technical Conference and Exhibition, Dallas, TX, USA, 22-25 October 1995. [CrossRef]

13. Kováč, M.; Nagymarosy, A.; Oszczypko, N.; Ślączka, A.; Csontos, L.; Marunteanu, M.; Matenco, L.; Márton, E. Palinspastic reconstruction of the Carpathian-Pannonian region during the Miocene. In Geodynamic Development of the Western Carpathians; Rakúš, M., Ed.; Slovak Geological Survey (GSSR): Bratislava, Slovakia, 1998; pp. 189-217.

14. Golonka, J.; Pietsch, K.; Marzec, P. Structure and plate tectonic evolution of the northern Outer Carpathians. In Tectonics; Closson, D., Ed.; INTECH: Rijeka, Croatia, 2011; pp. 65-92.

15. Porębski, S.J.; Warchoł, M. Hyperpycnal flows and deltaic clinoforms-Implications for sedimentological interpretations of late Middle Miocene fill in the Carpathian Foredeep Basin. Prz. Geol. 2006, 54, 421-429.

16. Borys, Z. Aktualne problemy poszukiwań węglowodorów we wschodniej części przedgórza Karpat. Prz. Geol. 1996, 44, 1019-1023.

17. Myśliwiec, M. Poszukiwania złóż gazu ziemnego w osadach miocenu zapadliska przedkarpackiego na podstawie interpretacji anomalii sejsmicznych—podstawy fizyczne i dotychczasowe wyniki. Prz. Geol. 2004, 52, 299-306. 
18. Myśliwiec, M. Typy pułapek gazu ziemnego i strefowość występowania ich złóż w osadach miocenu wschodniej części zapadliska przedkarpackiego. Prz. Geol. 2004, 52, 657-664.

19. Myśliwiec, M. Żołynia-Leżajsk—stare złoże, nowe zasoby. Nafta-Gaz 2006, 3, 97-105.

20. Myśliwiec, M.; Madej, K.; Byś, I. Złoża gazu ziemnego w osadach miocenu rejonu Rzeszowa (zapadlisko przedkarpackie) odkryte na podstawie wyników nowoczesnej kompleksowej interpretacji danych sejsmicznych. Prz. Geol. 2004, 52, 501-506.

21. Myśliwiec, M.; Borys, Z.; Bosak, B.; Liszka, B.; Madej, K.; Maksym, A.; Oleszkiewicz, K.; Pietrusiak, M.; Plezia, B.; Staryszak, G.; et al. Hydrocarbon resources of the Polish Carpathian Foredeep: Reservoirs, traps, and selected hydrocarbon fields. In The Carpathians and Their Foreland: Geology and Hydrocarbon Resources; Golonka, J., Picha, F.J., Eds.; AAPG: Tulsa, OK, USA, 2006; Volume 84, pp. 351-393.

22. Rzemieniarz, A. Analiza zmienności wybranych parametrów petrofizycznych utworów struktury Palikówka. Nafta-Gaz 2004, 11, 561-569.

23. Chmielowska, A.; Sowiżdżał, A.; Tomaszewska, B. Prospects of Using Hydrocarbon Deposits from the Autochthonous Miocene Formation (Eastern Carpathian Foredeep, Poland) for Geothermal Purposes. Energies 2021, 14, 3102. [CrossRef]

24. Górka, A.; Gliniak, P.; Madej, K.; Maksym, A. Oil and gas fields in the Carpathians and the Carpathian Foredeep. Prz. Geol. 2007, 55, 993-998.

25. Sowiżdżał, K.; Słoczyński, T.; Matyasik, I.; Stadtmüller, M. Analiza paleozoicznego systemu naftowego w strefie brzeżnej nasunięcia Karpat fliszowych. Nafta-Gaz 2015, 9, 632-646.

26. Wójcik, K.; Peryt, T. Pakiet Danych Geologicznych do Postępowania Przetargowego na Poszukiwanie Złóż Wẹglowodorów, Obszar Przetargowy "Błażowa"; Państwowy Instytut Geologiczny_Państwowy Instytut Badawczy: Warszawa, Poland, 2016.

27. Maksym, A.; Dziadzio, P.; Liszka, B.; Staryszak, G. Środowisko sedymentacji utworów miocenu autochtonicznego w brzeżnej strefie Karpat, a interpretacja geologiczno-złożowa w obszarze Husów-Albigowa-Krasne. Naft. Gaz 1997, 9, 407-414.

28. Dziadzio, P. Sekwencje depozycyjne w utworach badenu i sarmatu w SE części zapadliska przedkarpackiego. Prz. Geol. 2000, 48, $1124-1138$.

29. Seright, R.S.; Lane, R.H.; Sydansk, R.D. A Strategy for Attacking Excess Water Production. In Proceedings of the SPE Permian Basin Oil and Recovery Conference, Midland, TX, USA, 15-17 May 2001. [CrossRef]

30. Chan, K.S.; Bond, A.J.; Keese, R.F.; Lai, Q.J. Diagnostic Plots Evaluate Gas Shut-Off Gel treatments at Prudhoe Bay, Alaska. In Proceedings of the Technical Conference and Exhibition, Denver, CO, USA, 6-9 October 1996. [CrossRef]

31. Seldal, M. Using Water/Oil Ratios to Diagnose Excessive Water Production Mechanisms. Master's Thesis, New Mexico Institute of Mining and Technology, Socorro, NM, USA, 1997.

32. Seright, R.S. Improved Methods for Water Shutoff. In Annual Report DOE/PC/91008-14; New Mexico Institute of Mining and Technology: Socorro, NM, USA, 1998.

33. Kozeny, J. Ueber kapillare Leitung des Wassers im Boden. Sitz. Akad. Wiss. Wien 1927, 136, 271-306.

34. Carman, P.C. Fluid flow through granular beds. Inst. Chem. Eng. 1937, 32-48. [CrossRef]

35. Carman, P.C. Flow of Gases through Porous Media; Butterworths: London, UK, 1956.

36. Tixier, M.P. Evaluation of Permeability from Electric-Log Resistivity Gradients. Oil Gas J. 1949, 48, 113-122.

37. Timur, A. An Investigation of Permeability, Porosity, and Residual Water Saturation Relationship for Sandstone Reservoirs. Log Anal. 1968, 9, 8 .

38. Coates, G.R.; Dumanoir, J.L. A New Approach to Improved Log-Derived Permeability. Log Anal. 1974, 1, 17.

39. Schlumberger Ltd. Log Interpretation Charts; Schlumberger Ltd.: Houston, TX, USA, 1987.

40. Zawisza, L.; Nowak, J. Metodyka Określania Parametrów Filtracyjnych Skał na Podstawie Kompleksowej Analizy Geofizyki Otworowej; AGH University of Science and Technology Press: Kraków, Poland, 2012.

41. Botermans, C.W.; Calrymple, E.W.; Dahl, J.; Smith, D. Chemical system for water and gas control: Terminology, evaluation methods, candidate selection and expectations. In Proceedings of the SPE International Symposium on Oilfield Chemistry, Houston, TX, USA, 13-16 February 2001. [CrossRef]

42. Lakatos, I.J.; Lakatos-Szabo, J.; Szentes, G.; Vago, A. New Alternatives in Conformance Control: Nanosilica and Liquid Polymer Aided Silicate Technology. In Proceedings of the SPE European Formation Damage Conference and Exhibition, Budapest, Hungary, 3-5 June 2015. [CrossRef]

43. Lakatos, I.J.; Szentes, G.; Toro, M.; Karaffa, Z.; Vago, A. Mitigation of Formation Damage Caused by Chemical Overdosing in Water Shut-Off Treatments. In Proceedings of the SPE International Conference and Exhibition on Formation Damage Control, Lafayette, LA, USA, 19-21 February 2020. [CrossRef]

44. Seright, R.S.; Brattekas, B. Water shutoff and conformance improvement: An introduction. Pet. Sci. 2021, 18, 450-478. [CrossRef] 